\title{
A literature survey of the influence of preform reheating and stretch blow molding with hot mold process parameters on the properties of PET containers Part II
}

\author{
Paweł Wawrzyniak ${ }^{1), *)}$, Waldemar Karaszewski ${ }^{2)}$ \\ DOI: dx.doi.org/10.14314/polimery.2020.6.3
}

\begin{abstract}
The paper presents a wide analysis of the literature on the modified blow molding process with simultaneous stretching of PET [poly(ethylene terephthalate)] material for storing hot filled drinks. The paper is a continuation of the first part presented earlier [1]. In this part it is presented in detail the impact of stretch blow molding with hot mold process parameters on thermal resistance of PET containers. An analysis of the literature shows that the relaxation of the amorphous phase has the greatest impact on the thermal stability and pressure resistance of the bottle. At the same time, the thermal stability of the bottle increases, and the pressure strength decreases when the relaxation of the amorphous phase is increased, and the crystallites increase to the largest size possible without causing thermal whitening of the material. The measure of relaxation of the amorphous phase is based on the amount of oriented and "rigid" amorphous phase, since the higher the degree of relaxation of the amorphous phase, the smaller the amounts of oriented and rigid amorphous phase. The main parameters of the hot mold SBM process that affect the properties of the hot filling bottle are the intrinsic viscosity of the preform material, the power profile of the heating lamps in the heating oven (there are seven levels of heating lamps), the heating time in the oven and the associated time of temperature-induced crystallization prior to the SBM process, the speed of the stretching rod, the pre-blow delay due to the stretching rod position, the pre-blow pressure, pre-blow duration, air blow pressure, duration of the main blow, temperature profile of the heated blow mold (there are two heat zones for the blow mold, the lateral surface of the bottles and base zone), duration of annealing in the mold, cooling air temperature of a bottle in a blow mold fed by a stretching rod, and the pressure in the feed branch for air cooling of a bottle in a blow mold fed by a stretching rod. Thus, the properties of a bottle or hot fill can be influenced by as many as 20 factors during the SBM process with a hot mold.
\end{abstract}

Keywords: stretch blow molding process, hot filling process, structure of PET material, hot fill PET bottles.

\section{Przegląd literatury dotyczącej wpływu parametrów procesu rozdmuchiwania $\mathrm{z}$ jednoczesnym rozciąganiem $\mathrm{z}$ zastosowaniem gorącej formy rozdmuchowej na właściwości pojemników PET. Cz. II.}

Streszczenie: Artykuł jest kontynuacją I części [1], w której przedstawiono szeroką analizę literatury dotyczącej zmodyfikowanego procesu rozdmuchiwania z jednoczesnym rozciąganiem tworzywa PET [poli(tereftalanu etylenu)] - w celu wytworzenia butelek do przechowywania napojów nalewanych na gorąco. W części drugiej szczegółowo opisano zależność odporności termicznej pojemników PET od przebiegu procesu rozdmuchiwania z jednoczesnym rozciąganiem. $\mathrm{Z}$ analizy literatury wynika, że największy wpływ na stabilność termiczną i wytrzymałość mechaniczną butelki ma relaksacja fazy amorficznej. Stabilność termiczna butelki rośnie, a wytrzymałość na ciśnienie się zmniejsza, gdy zwiększa się relaksacja fazy amorficznej, a kryształy osiągają możliwie największe wymiary, niepowodujące termicznego zabielenia materiału. Miarę relaksacji fazy amorficznej w tworzywie stanowią udziały zorientowanej i „sztywnej” fazy amorficznej, ponieważ im wyższy stopień relaksacji, tym mniejsze

1) Warsaw University of Technology, Faculty of Automotive and Construction Machinery Engineering, Narbutta 84, 02-524 Warsaw, Poland.

2) Gdansk University of Technology, Faculty of Mechanical Engineering, Narutowicza 11/12, 80-233 Gdansk, Poland.

*) Author for correspondence: pawel.wawrzyniak@pw.edu.pl 
ich ilości. Na właściwości butelki przeznaczonej do nalewania na gorąco może wpływać aż 20 parametrów procesu rozdmuchiwania z jednoczesnym rozciąganiem z gorącą formą. Główne czynniki to: lepkość istotna materiału preformy, profil mocy lamp grzewczych w piecu grzewczym (istnieje siedem poziomów lamp grzewczych), czas ogrzewania preform w piecu i związany z nim czas krystalizacji indukowanej temperaturą przed procesem SBM, prędkość pręta rozciągającego, opóźnienie wstępnego rozdmuchu względem położenia pręta rozciągającego, ciśnienie i czas trwania wstępnego rozdmuchu, ciśnienie i czas trwania głównego rozdmuchu, profil temperaturowy podgrzewanej formy rozdmuchowej (istnieją dwie strefy grzewcze dla formy rozdmuchowej, powierzchnia boczna i strefa denka), czas trwania wyżarzania $\mathrm{w}$ formie, temperatura i ciśnienie powietrza chłodzącego butelkę $\mathrm{w}$ formie rozdmuchowej doprowadzanego przez pręt rozciągający.

Słowa kluczowe: proces formowania opakowań metodą rozdmuchu z rozciąganiem, nalewanie napojów na gorąco, struktura opakowań PET, opakowania PET przystosowane do nalewania na gorąco.

The paper is a continuation of the first part presented in [1]. The first part describes orientation and crystallization process in SBM (stretch blow molding) technology. In hot fill technology especially crystallization process plays important role where high thermal bottle stabilization is required. The elements of the PET material structure were described in terms of thermal stability and mechanical strength. In the first part the forming process of hot fill PET bottles was also described. The complete hot filling process involves the production of the appropriate PET granulate, formation of the preform in the injection molding process, formation of a hot filling container, pasteurization and pouring of the beverage, bottle closure and cooling of the beverage within the closed bottle.

\section{CHARACTERIZATION OF THE SBM PROCESS WITH HOT MOLD}

There are several techniques for producing hot fill PET bottles by the SBM process with an annealing step, which can be considered as a non-crystalline phase relaxation process [2], including:

- blowing and annealing the bottle in one heated mold; this is the longest-established method, which makes it possible to produce thermally stable bottles up to $80^{\circ} \mathrm{C}$, since it is not possible to overheat the mold as the bottle strongly deforms after the blow air pressure is removed;

- blowing and annealing the bottle in one heated blow mold, while cooling the inner wall of the bottle with cold compressed air during annealing. Simultaneously cooling the bottle from the inside can raise the temperature of the blow mold without deforming the bottle when it is removed from the mold;

- use of double blow molding; this is the most recently proposed method and can obtain bottles with the highest thermal stability, reaching $95^{\circ} \mathrm{C}$ or even $100^{\circ} \mathrm{C}$ [3]. However, this technique has not been widely accepted due to the high investment costs and the difficulty of setting parameters.

It should be mentioned that in addition to a higher thermal strength due to greater amorphous phase relaxation, the double blow molding process gives a bottle that also has a higher barrier to oxygen, carbon dioxide and water vapor than from a process using one mold, due to the creation of more perfect crystallites without an increase in the free volume of the amorphous phase [4].

Further methods of annealing in a single hot mold that have not yet been commercially accepted for the SBM process but are undergoing scientifically development include:

- annealing in a mold heated to temperatures almost equal to the melting point of PET [2];

- simultaneous annealing using hot air blown from the inside of the bottle, during hot mold annealing of the outside of the bottle [2];

- simultaneous annealing with hot steam (to increase the penetration of heat into the bottle wall) from the inside of the bottle, during hot mold annealing of the outside of the bottle [2];

- simultaneous annealing with hot blown air from the inside of the bottle and annealing from the inside of the bottle with infrared lamps built into the stretching rod, during hot mold annealing [2]; however, the fitting of such lamps poses difficulties, and the efficiency of heating has a strong dependence on the distance between the lamp and the wall of the bottle;

- the embedding of an organic solvent such as acetaldehyde [5] or toluene [3] into a preform to improve the crystallinity and to draw and blow mold the preform only once; following this, the preform with improved thermal resistance can be molded at a relatively low temperature of approximately $80^{\circ} \mathrm{C}$, which is slightly higher than the glass transition temperature [3];

- development of a new post-processing method to realise the spatial selective annealing of materials [6]. Beyond conventional heating using infrared lamps, microwaves [7], photothermal [8-14], magnetism [15, 16], electricity [17-19] and ultrasound [20-27] can be used to heat the polymer-based material. Of these, photothermal heating may be the most accurate spatially-selective heating method [6]. Ultrasound waves have the ability to penetrate much deeper into the interior of materials than light $[28,29]$. When ultrasound waves pass through solid 
polymer materials, a viscous shearing oscillation of the polymer chain is induced by focused ultrasound. This subsequently relaxes, releasing the energy in the form of heat. When focused, high-intensity focused ultrasound can concentrate acoustic energy over a small area, and since polymers are generally poor thermal conductors, these sound waves can readily be directed to interact with a polymer over a selected area and to heat it above a target temperature within only a few seconds [25].

In this paper only one process will be discussed: blowing and annealing the bottle in a single heated blow mold while cooling the inner wall of the bottle with cold compressed air during annealing. This process involves the following steps: (A) heating the preform in the heating furnaces; (B) transporting the preforms from the heating furnaces to the blow molds; (C) sequentially forming the bottles in the hot mold (stretching via rod, pre-blowing and main blowing); (D) holding the bottle in the hot mold under the main blowing pressure; (E) opening the cooling air valve and cooling the inner surface of the bottle wall, with cold air flowing out of the stretching rod (i.e. balayage stretching rod [30]) under the main blow pressure or lower $(\mathrm{F})$; and $(\mathrm{G})$ removing the air from the blow mold. These steps are shown in Fig. 1 with an indication of the range of times and pressures used and the timeframe of the blow molding machine cycle for the production of cold fill bottles (TC) and hot fill bottles (TH).

The SBM process cycle time for the production of cold fill bottles is about 0.4 to 5 seconds, depending on the weight and volume of the bottle; due to the additional

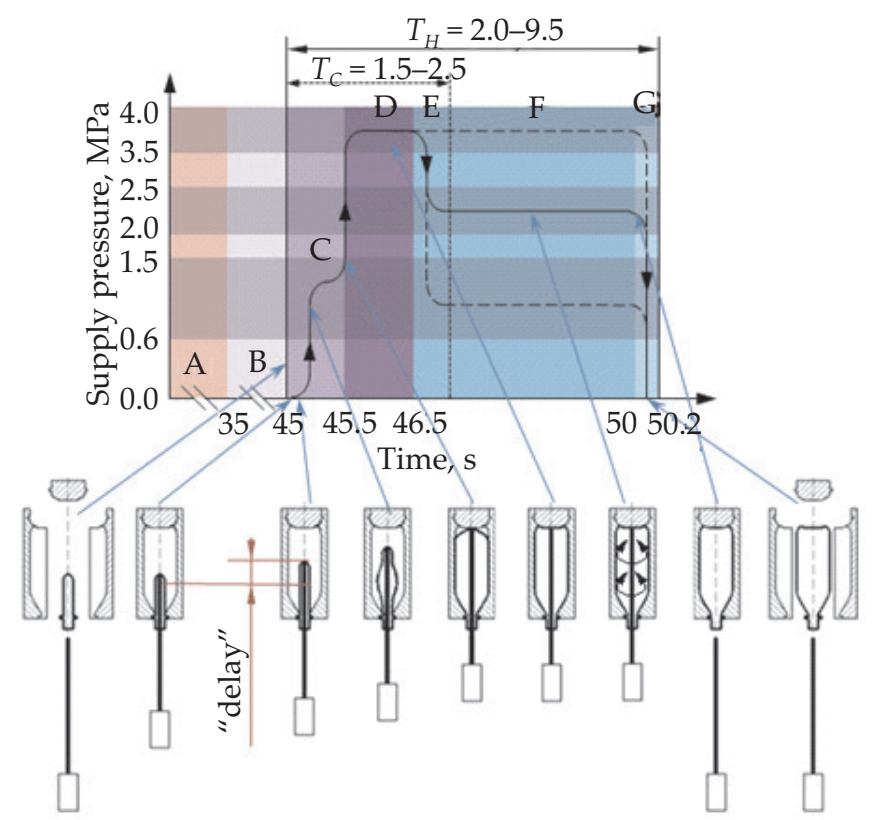

Fig. 1. Schematic representation of the pressure changes of blown air during the production of a thermally stable PET bottle in hot form over the whole process, where TC - cold fill PET bottle cycle time production, TH - hot fill PET bottle cycle time production (the meanings of the other letters are explained in the text) annealing cycle, the SBM process cycle for hot fill bottles is extended to about $2-9$ seconds. This significantly reduces the efficiency of the blow molding machines used to make hot filling bottles.

In the SBM process with a hot mold machine, the infrared radiators first heat the preform to the highest possible working temperature, between the glass transition temperature (about $80^{\circ} \mathrm{C}$ ) and the crystallization temperature (about $120^{\circ} \mathrm{C}$ ), which is the maximum possible temperature without inducing temperature whitening. Preheating the preform to the highest possible temperature makes it difficult to create durable non-crystalline structures during SBM deformation; at the deformation speeds used in the SBM process at temperatures of between $110^{\circ} \mathrm{C}$ and $120^{\circ} \mathrm{C}$, there is no occurrence of oriented crystalline structures [31], which would demonstrate the orientation of the non-crystalline phase, i.e. the nematic and smectic mesophases. It is worth noting, however, that the higher the deformation temperature (i.e. the higher the temperature of the preform), the higher the value of the SHP parameter (strain-hardening parameter, or natural draw ratio) [32], and thus it is harder to control the distribution of the material along the axis of the bottle during its formation. The effective wavelength range for IR heating is about 1 to $2 \mu \mathrm{m}$, at which PET is semitransparent [33].

When the heated blow mold is closed, the preform is stretched and blown into the shape of the finished bottle (mold). The temperature of the mold is about $120-130^{\circ} \mathrm{C}$, and this is optimized for the efficiency of production and quality of the heat treatment of the bottle after formation. The temperature used in the hot mold method is limited by the ability to remove the bottle from the mold without distortion. The blow mold is typically heated to $130^{\circ} \mathrm{C}$, and as the mold temperature rises, it becomes increasingly difficult to remove the bottle without deformation. The maximum mold temperature for safe removal of the bottle, assuming conventional air cooling, is approximately $180^{\circ} \mathrm{C}$ [2], and a typical mold temperature is about $150^{\circ} \mathrm{C}$ [4]. However, in the experience of the present authors, it appears that at blow mold temperatures of higher than $140^{\circ} \mathrm{C}$, there is uncontrolled melting of the exterior surface of the container walls. This molten PET material sticks to the walls of the blow mold, preventing the container from being properly formed. Above temperatures apply to the body of the bottle. The bottle neck cannot be heated, so the mold cannot have a temperature higher than $35^{\circ} \mathrm{C}$, where the neck touching the mold. Also, the bottom part of the blow mold, due to the deformation process after leaving the bottle from the mold, cannot exceed $60-65^{\circ} \mathrm{C}$.

Once formed, the bottle is annealed in this mold for 0.5 to 8 seconds before the mold is opened. During this period, compressed air at room temperature is usually circulated inside the bottle to cool it and reduce the temperature of the internal wall surface of the bottle to a temperature at which the bottle can be removed from the 
mold without deformation. The basic effect obtained is the relaxation of the oriented amorphous phase, which allows the bottle to withstand further exposure to elevated temperatures during the hot filling process. Since the bottle is subjected to compressed air during annealing, this can be treated as constrained annealing. The crystallinity during annealing is only slightly increased compared to that caused by the stretching process during deformation of the preform (since the size of the crystallites is growing), but the relaxation of the amorphous PET phase is significantly increased [2].

The heat transfer from the heated mold reduces the internal stresses in the material due to the fact that within this range of temperatures, the non-crystalline phase is relaxed, since intensive creep and retraction processes result in increased crystallinity of the material. As discussed above, an increase in preform temperatures leads to fewer amorphous oriented structures at the time of bottle molding, and thus less residual stress in the amorphous phase of the finished bottle, which translates to reduced thermal shrinkage during hot filling. The residual stresses in the finished bottle can be measured using digital photoelasticity [34]. However, the temperature of the mold is not the only important factor in reducing the stresses in the amorphous phase, and the time spent in the heated mold also plays an important role. To maximise the thermal stability of the bottle as far as possible, the relaxation of the non-crystalline phase should be maximized, with as much crystallite growth as possible. This blocks the movement of macromolecules of the amorphous phase surrounding these crystallites, hindering further crystallization of the amorphous matrix material. Hence, increased crystallinity increases the thermal stability of the bottle; although the crystalline phase itself is stable to its melting point, the thermal stability of the PET bottle does not arise directly from the crystalline phase but from the fact that the stable crystalline phase hinders the movement of the unstable non-crystalline macromolecule phase surrounding the crystallites (at temperatures above the glass transition temperature, these macromolecules could crystallize, which would cause a volume contraction of the bottle). The annealingtime does not depend solely on the wall thickness of the bottle, but also on the size ratio of the bottle relative to the preform. The larger the size of the container relative to the preform, the longer the annealing process takes, since the larger the container, the higher the ratio of deformations, which translates into an increased number of oriented amorphous phases. This is why hot fill bottles are usually no larger than 1 liter. Nevertheless, attempts are being made to use this technology for bottles up to 3 liters (Nissei ASB).

However, the crystallite size should not be increased too much, as the barrier properties of the material are greatly reduced (including the barrier to oxygen, which reduces the storage period for the beverage in the container) due to the presence of the non-crystalline phase in the crystallite agglomerations. In addition, the bottle after removal blowing air can cause very strong shrinkage, and crystallites that are too large may cause thermal whitening of the material. The reduction of the barrier properties can be compensated for by increasing the wall thickness of the container, which additionally slightly increases the container's thermal strength. More importantly, increasing the annealing time reduces the efficiency of the blow molding machine, and increasing the mold temperature increases the cost of producing a bottle, which is very undesirable.

Since most hot filling processes involve a relatively short-term exposure of the bottle to a high temperature, in order for the bottle not to be deformed during hot filling process it must have a half-time for relaxation that is long enough that the exposure time to high temperatures is insufficient to initiate contraction. This can be achieved by the use of an appropriate time and annealing temperature.

Since PET fills the mold cavity during blowing, the air inside the cavity must be expelled, and mold manufacturers add a variety of vents for this purpose. Vent sizes are limited to $0.04 \mathrm{~mm}$ in injection molding, but vents of up to $1 \mathrm{~mm}$ in the panel area of a hot fill bottle are used in the reheat stretch blow molding process [35].

Before opening the mold, the bottle should theoretically be cooled to the highest possible temperature at which it can be removed without the appearance of deformation [2]. This result is not widely accepted and appreciated in the PET bottle industry, and instead, the bottle in the hot mold is cooled down as far as possible. In addition, to lower the temperature inside the bottle before filling a hot beverage, the bottle is briefly blown with compressed air to remove the hot air from the bottle and to cool down the bottle.

The final temperature of the bottle after annealing has a strong determinant effect on the thermal stability of the bottle, due to the kinetic nature of the relaxation of amorphous chains. When the internal pressure holding the bottle in the mold is removed, the bottle will shrink as a result of the removal of this restriction, which prevented the relaxation of the amorphous region. The speed of this relaxation depends on the final temperature of the bottle after annealing. Bottles removed at higher temperatures will be cooled below the glass transition temperature outside the mold for a longer period of time, and due to the relaxation movements of the amorphous regions, more amorphous areas will undergo stress relaxation. The smallest value of the residual stress will occur after the bottle is removed from the hot blow mold, as the speed of cooling will be infinitely small. The lower the temperature of removing the bottle from the mold, the higher the level of residual stress that will reduce the thermal stability of the bottle during hot filling. However, it should be noted that these relaxation processes cause a contraction of the bottle, which deforms its shape compared to that of the blow mold. The shrinkage that occurs after anneal- 
ing and its kinetics depend on the time and temperature of annealing, meaning that a compromise is required between the thermal stability and quality of the shape of the bottle.

In the hot blow mold, the bottle is cooled by compressed air circulation, which is fed through the channels and holes in the hollow balayage stretch rod and is delivered to the critical areas of the bottle wall. Due to the additional process steps required, the heat-stabilizing SBM process typically requires longer processing times and greater air consumption than the standard SBM process. Outside the blow mold, the bottle is also cooled by compressed air.

In summary, greater relaxation of the oriented amorphous phase, higher crystallinity and thicker side walls of bottles are useful ways of retarding the occurrence of shrinkage at higher temperatures, to allow bottles to be used under the desired hot filling conditions. It has been noted that bottles annealed at higher blow mold temperatures exhibit higher thermal stability, since higher temperatures favor a higher degree of relaxation of noncrystalline areas. In practice, this may be due to another factor: higher mold temperatures require the preforms to be warmed to higher temperatures to minimize heat shrinkage from blow molds, and this higher preform temperature may be a more significant factor in improving thermal stability than the blow mold temperature [2].

\section{INFLUENCE OF DEFORMATION AND TEMPERATURE ON THE THERMAL RESISTANCE OF PET MATERIAL}

Structure development is a key issue in polymer processing, and arises under complex, inhomogeneous, coupled mechanical (flow, pressure), thermal (cooling rate, temperature gradient) and geometrical (surface of processing tools) conditions. Several phenomena are involved, of which crystallization and orientation play a major role. Furthermore, the crystallization and orientation are also conditioned by the initial arrangement and distribution of macromolecules and crystallites, and due to the limited computing power of computers, this can only be described in macroscopic terms in the form of equations that give the average behavior over the entire process. The samples obtained via the SBM process are very inhomogeneous, and it is therefore very difficult to draw reasonable conclusions about the influence of SBM process parameters on microstructure development in PET. A significant impediment to an understanding of structure development is the difficulty of designing model experiments that can isolate the specific influence of a given parameter [36].

Today, non-isothermal crystallization can be modelled using general differential equations. These are suitable for numerical simulation, can represent both isothermal and non-isothermal crystallization, and can be extended to take into account the flow, pressure, confinement and surface effects. However, there is a still a lack of data on the elementary steps of nucleation and growth (e.g. the growth rate under pressure), and on the correlation between the development of morphologies and the overall kinetics [36].

Strain-induced crystallization only occurs alongside temperature-induced crystallization (although temperature-induced crystallization may occur alone), but the sudden crystallization of PET caused by deformation limits temperature-induced crystallization. However, in the case of cold crystallization, this is only valid for temperatures in the range $110-150^{\circ} \mathrm{C}$ [37], since at temperatures between the glass transition temperature and $110^{\circ} \mathrm{C}$, temperature-induced crystallization can be neglected compared to strain-induced crystallization. From tests carried out on the polypropylene, the crystallization kinetics of the polymeric material are also known to be affected by the pressure at which the crystallization takes place. In addition, the higher the pressure, the faster the crystallization kinetics of the PP material, although no similar testing of PET material has been carried out [36].

Perhaps the most important feature of a bottle intended for hot filling is its resistance to thermal shrinkage. However, each hot fill bottle used commercially must meet certain minimum requirements [38], including:

- top loading, which is required during palletizing (storage of one bottle set on the other - minimum values $120 \mathrm{~N}$ for 0,5 litres bottles);

- impact resistance (drop impact resistance - no bottle deformation at a drop from minimum 1 meter);

- resistance to bottom deformation (minimum 0.1 $\mathrm{MPa}$ for nitrogen expansion);

- thermal stability (minimum up to $45^{\circ} \mathrm{C}$, for hot countries up to $50^{\circ} \mathrm{C}$ );

- uniform distribution of material in the bottle (the wall thickness difference may not exceed $10 \%$ over the entire surface of the bottle, the value does not apply to the bottom area and area directly under the bottle neck);

- stress cracking (defining by the duration of causing stress cracking test, defined individually);

- barrier to gases (especially oxygen - depends on the product type, shelf life requirements, must be defined individually).

It is worth emphasizing that an increase in thermal stability can simultaneously worsen the other properties of bottles, and in particular the crack resistance and barrier properties. The thermal stability of hot filled bottles is also lowered when they are stored at high ambient temperatures and humidity; due to the hygroscopicity of PET, it absorbs moisture, and as the moisture content in the PET material increases its glass transition temperature decreases [39].

There are generally three methods of measuring shrinkage as a measure of the thermal stability of the bottle:

- Filling the bottle with a hot water (to below $100^{\circ} \mathrm{C}$ ), holding the hot water for some time in the open bottle at 
room temperature, pouring out the water and checking the volume of the bottle after emptying $[2,5]$ (alternatively, the shrinkage of the bottle can be checked based on the difference in the volume before and after holding the hot water).

- Holding the empty container in an autoclave at an elevated pressure and a temperature of above $120^{\circ} \mathrm{C}$ $[2,40,41]$.

- Cutting out a sample from the bottle and subjecting it to a dynamic mechanical analysis (DMA) or thermal mechanical analysis (TMA) or using a shrinkage dilatometer [41-44].

Of course, there are many more methodologies for measuring the thermal resistance of the bottle. For example, Demirel and Daver [45] described research into the thermal resistance of a CSD bottle with differing preform reheat temperatures (made using SBM process with a cold mold) by measuring the dimensional changes in filled carbonated PET beverage bottles that were induced by the thermal stresses that occur over the life of the filled bottle. The bottles were filled with the prepared solutions [carbon dioxide $\left(\mathrm{CO}_{2}\right)$ was generated via the reaction between citric acid and sodium carbonate in water] and were kept at $38^{\circ} \mathrm{C}$ for $24 \mathrm{~h}$ and then at $22^{\circ} \mathrm{C}$ for $4 \mathrm{~h}$. After a waiting period, the dimensional changes in the bottle were recorded in terms of percentages.

There were measurable changes in the clearance of the bottle base from the ground, the bottle height, the fillpoint drop (i.e. the distance between an inscribed reference line and the bottom of the product meniscus), the body diameter (in terms of upper body, lower body, and base), and the bottle perpendicularity. The increase in the lower body and base sections of the bottle decreased with increasing preform temperature, but in the upper body section, the growth was not affected by the preform reheat temperature. The fill-point drop is the most important thermal stability parameter from a visual point of view, and reaches a minimum value at a preform reheat temperature of $110^{\circ} \mathrm{C}$. However, the percentage change in clearance increases as the preform reheat set temperature increases. Once the preform reheat temperature reaches $110^{\circ} \mathrm{C}$, the bottle base becomes overly concave-shaped, and the bottle loses its self-standing property [45].

The hot water filling method examines the temporary resistance of the bottle to thermal shrinkage, while the autoclave method explores the long-term resistance of the bottle to thermal shrinkage and the effects of aging. The method of testing cut samples allows us to analyze the microstructure of the material, but this is the most laborious and least representative method; due to the huge difference in the properties of different areas of the same bottle, it is difficult to identify an area representing the entire bottle. Since the total shrinkage of the bottle is the sum of all the local shrinkages, shrinkage testing of the bottle as a whole provides a reliable and comparable mean shrinkage effect. Since the most important feature of the hot fill process is the short-term resistance of the bottle to thermal shrinkage, the hot water filling method has been adopted to measure shrinkage.

In addition to the phase structure of the material, the physicochemical properties of the bottle also affect the wall thickness of the bottle. Any change in design or process results in a change in the thickness distribution at different points in the bottle, and a quantitative thickness measurement can provide feedback to improve the design or process. Thickness measurements are also correlated with the microstructure of the local material (for example, the bottle wall may deform under the influence of forces from the measuring device), which affects the physical and mechanical properties [46]. As non-destructive tools for measuring thickness, X-ray tomography, IR-based or Hall effect-based (e.g. Magna-Mike) measurement devices are very well tested [47]. Some methods are slow or expensive. Destructive tools for thickness measurement include the use of micrometers and measurements of the cross-sectional thickness profile of the bottle using an optical scanner; the low cost of the latter method has been proven by Allahkarami et al. [47]. Since Hall effect-based thickness measurements are fast and inexpensive, these are adopted to measure the thickness profile of the bottle.

Mody et al. [41] discussed in detail the behavior of PET film under static and dynamic heating. Static annealing consisted of holding uniaxially and biaxially deformed PET samples at a constant temperature, while dynamic annealing consisted of heating the deformed PET samples to varying temperatures, increasing at a constant rate of $5^{\circ} \mathrm{C} / \mathrm{min}$. In addition to testing the effect of the deformation method for the sample, the impact of the deformation velocity (strain rate) was also tested at $0.5 / \mathrm{s}$ and $2 / \mathrm{s}(50 \% / \mathrm{s}$ and $200 \% / \mathrm{s})$. The degree of crystallinity and the orientation of the amorphous phase were also tested. The research presented in the article shows that the percentage of shrinkage is determined by the state of orientation of the amorphous phase and the degree of crystallinity of the material in the PET sample. The shrinkage decreases as the deformation speed increases for samples stretched both in uniaxial and biaxial modes. Higher deformation velocities minimize the relaxation process and lead to a more dimensionally stable crystalline phase, through an increase in strain-induced crystallinity, which impedes the contraction process. However, it must be strongly emphasized that according to other studies [44], the change in the stretching speed under uniaxial tension from $1.2 / \mathrm{s}$ to $5 / \mathrm{s}$ had no effect on the shrinkage value. It follows that for low deformation speeds only, the increase in speed counteracts the shrinkage, since for speeds above $1 / \mathrm{s}$, the strain-induced crystallization process takes place only after the deformation process has been completed, what was also reported by Mahendrasingam et al. [31].

Moreover, according to the studies described by Shih [44], neither a change in the stretching speed nor a change in the stretching temperature from $90^{\circ} \mathrm{C}$ to $120^{\circ} \mathrm{C}$ (the tem- 
perature at which the stretching takes place) had a significant effect on the temperature at which the shrinking process of the sample started (known as the onset shrink temperature), although it is worth emphasizing that a large increase in the temperature of stretching slightly decreased the value of the onset shrink temperature. However, the speed of shrinkage and its final value decreased significantly as the temperature of the PET sample increased, probably because the polymer chains relax more when stretched at higher temperatures, since the higher stretching temperature leads to greater relaxation of the amorphous phase. This explains the behavior of PET in the SBM process with a hot mold, where it is observed that the higher the temperature of the preform, the higher the thermal resistance of the bottle [2].

The research described by Mody et al. [41] shows that the degree of crystallinity, the birefringence and the orientation function of the amorphous phase increase with increases in the elongation coefficient and the stretching rate. Shrinkage arises as a result of chain disorientation in the amorphous phase. The disorientation process is more difficult for biaxially oriented samples than for uniaxially oriented samples; the energies of shrinkage activation for biaxially oriented samples are higher than those for uniaxially oriented samples, indicating that the structures produced during biaxial orientation are more thermally stable and have improved dimensional stability compared to uniaxially oriented samples. The minimum temperature at which the shrinkage process begins (the onset shrink temperature) is higher for biaxial deformation than for uniaxial deformation.

Shih [44] argues that the first-order Avrami equation shapes the shrinkage process of uniaxially stretched PET film. In this equation for isothermal conditions, the three parameters used by the model to quantify the shrinkage of film at an elevated but constant temperature are the induction time, the shrink constant, and the ultimate shrinkage. In the non-isothermal condition, the onset shrink temperature, the shrink constant, and the ultimate shrinkage are the three parameters that characterize the process when shrink film is heated at a constant rate. The use of the Avrami equation shows that there is a constant rate of shrinkage with respect to the half time of shrinkage for uniaxially and biaxially oriented samples [41]. At the same time, it should be noted that the coefficient of shrinkage rate decreases with increasing deformation and deformation velocity and is lower for biaxial deformation than for uniaxial deformation.

Mody et al. [41] also proposed a schematic model describing the molecular changes occurring during the contraction of stretched PET films. It has been proposed that the entire shrinkage process is determined by three mechanisms: the strain-induced crystallization process, the amorphous phase orientation process, and the amorphous phase relaxation process. At the same time, two types of amorphous phase have been distinguished: the first between crystallites within microfibrils, and the

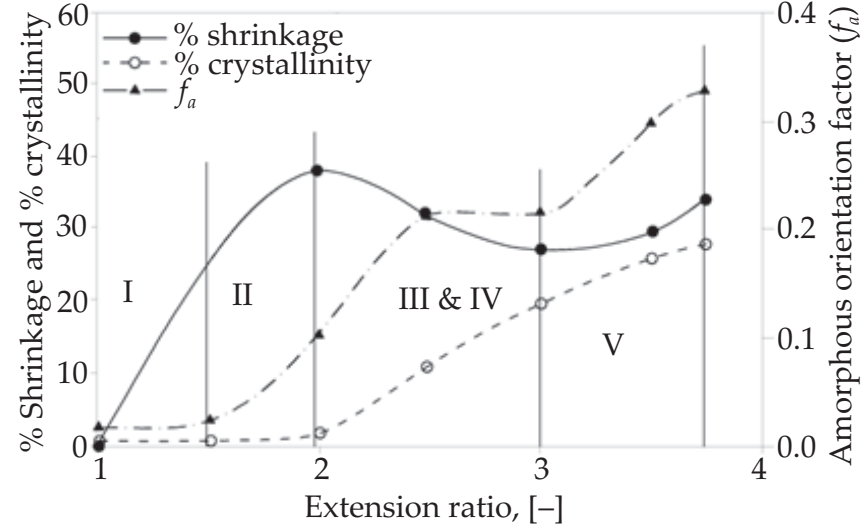

Fig. 2. Dependence of the degree of crystallinity, the measure of the amorphous phase orientation and the degree of shrinkage on the degree of deformation of the PET sample during uniaxial stretching at $2 / \mathrm{s}$, at a constant temperature of $100^{\circ} \mathrm{C}$, divided into five individual stages of shrinkage response [41]

second between microfibrils. Figure 2 shows the dependence of the degree of crystallinity, the measure of amorphous phase orientation and the degree of shrinkage on the degree of deformation of the PET sample during uniaxial stretching at $2 / \mathrm{s}$ at a constant temperature of $100^{\circ} \mathrm{C}$, divided into individual stages of shrinkage response. It is not known why the sample shows zero shrinkage for zero strain, and this phenomenon will not be analyzed later.

These three mechanisms overlap and affect each other, meaning that the material contraction depends on the degree of deformation, the strain rate and the deformation mode. The shrinkage response can be divided into five stages based on the degree of deformation. The higher the deformation speed and the more complex the deformation mode, the smaller and slower the shrinkage response, although the shape itself remains similar for the same strain ratio. Figure 2 shows that Stage I of the contraction response is characterized by the highest positive contraction gradient due to the increase in deformation, while the degree of crystallinity and the orientation of the amorphous phase do not change. In Stage II, the shrinkage value increases constantly as the deformation increases, but reaches a maximum at the end of the second stage. The degree of crystallinity does not change, while the orientation of the amorphous phase begins to grow rapidly. In Stages III and IV, deformed samples show lower shrinkage than in Stages I and II, and the degree of crystallinity of the material starts to increase. The orientation of the amorphous phase increases strongly but reaches a constant value at a certain point. In Stage V, the shrinkage value again begins to increase as the deformation increases, as do the degree of crystallinity and the orientation of the amorphous phase. This tendency of shrinkage $v s$. deformation has also been described by Weissmann [4].

This behavior can be explained on the basis of the molecular model adopted by Mody et al. [41] and described earlier in this paper. In Stage I, stretching 
leads to orientation in the amorphous phase without the noticeable development of crystallinity. Shrinkage arises as a result of the contraction of the binding molecules to give the most random conformation in the amorphous phase, as a result of which the chain (which at the beginning was extended, since it contained a larger number of trans conformations than gauche conformations of the ethylene glycol group along its length) wraps and shortens. Many continuum models have been developed to describe polymeric materials with regard to two possible conformational changes in the chain, and the physical and chemical changes in the microstructure and macroscopic properties of the material that are related to these changes. Brighenti et al. [48] show that the main aspects of the mechanical behavior of polymeric materials (using an example of PDMS - polydimethylsiloxane - material) with embedded switchable molecules are properly linked to the polymer's chains.

Measurements of the crystallinity of shrunken samples do not show significant growth, and thus the chains are in a random state after shrinkage. In Stage II, the contraction mechanism is the same as in Stage I, except that the binding molecules that are close together are recrystallized by folding the chain. The increase in the crystallinity of the shrunken sample confirms this hypothesis. In Stages III and IV, the mechanism of contraction changes from a stretched to a folded form. The binding chains become free from deformation after shrinkage, and are then incorporated into the crystallites, making it difficult to contract the bottle, and an increase in the crystallinity of shrunken samples is observed. In Stage $\mathrm{V}$, expanded amorphous particles play an important role in the mechanism of contraction. Shrinkage in this region occurs as a result of contraction of the binding molecules and the extended non-crystalline molecules. Parts of these extended non-crystalline molecules are absorbed by the crystallites, resulting in increased crystallinity of the shrunken samples.

It follows that the smallest value of shrinkage (the highest thermal resistance) is obtained for a degree of deformation of approximately three, i.e. the dimensions of the sample increase by a factor of three. This is also confirmed by research described by Shih [44], which shows that the higher the degree of deformation, the lower the shrinkage value for temperatures between $60^{\circ} \mathrm{C}$ and $80^{\circ} \mathrm{C}$, and the higher the onset shrink temperature. However, for temperatures above $85^{\circ} \mathrm{C}$, the tendency changes for a degree of deformation above three; for a value of four, the shrinkage of the PET sample is greater at a temperature of above $85^{\circ} \mathrm{C}$ than for a value of 3 . On the other hand, it is necessary to emphasize that the higher the degree of deformation, the greater the homogeneity of the thickness of the sample, meaning that the shrinkage is characterized by less rippling (deformation of the shape) of the sample.

These results are consistent with the SBM process. If the blown bottle has an inhomogeneous thickness at its circumference, it will deform in a very unfavorable way, and the bottle axis may be chamfered with respect to the plane of the bottle base. High rates and ratios of bottle deformation with respect to the preform are therefore needed to achieve a better homogeneity of the thickness around the circumference of the bottle. It should also be noted that the level of strain-induced crystallinity also depends on the initial blow ratio (the draw ratio from preform to bottle). The higher the draw ratio, the more oriented the material and the higher the rate of straininduced crystallization, giving a higher increase in crystallinity after annealing. However, for an orientation that is too high (i.e. a draw ration that is too high), the straininduced crystallization is very high, but no increase in crystallinity is seen on annealing [49]. Thus, the typical blow-up ratio for heat set bottles is $7: 1$, as compared with 15 : 1 for CSD (carbonated soft drinks) bottles [4].

There is lack of research describing the impact of preform temperature and mold temperature on the thermal resistance of the bottle in the SBM process with a hot mold. Demirel [50] describes the influence of the blowing mold temperature (between $5^{\circ} \mathrm{C}$ and $50^{\circ} \mathrm{C}$ ) and the residence time of the blown bottle in the blow mold (between 5 and $20 \mathrm{~s}$ ) and on the characteristics of the bottles, such as the material distribution, bottle burst strength, bottle top-load strength, crystallinity and glass transition temperature (for samples cut from the bottle label area). Blow mold temperatures were much lower than those used in the SBM with the hot mold process. However, these studies confirm the laboratory analyzes carried out on standardized PET samples showing that the degree of crystallinity of the bottle material cannot be fully correlated with the pressure resistance of the bottle.

Research has shown that the glass transition temperatures $\left(T_{0}\right)$, which are related to the amorphous structure of the material, are between $58.3^{\circ} \mathrm{C}$ and $59.4^{\circ} \mathrm{C}$ for all process conditions and are not related to an increase in the residence time in the mold. In contrast, the mold surface temperature was found to affect the $T_{g}$ values (the higher the mold temperature, the higher the glass transition temperature). Mold temperatures are used that are lower than the glass transition temperature of PET material, so the impact of the mold was not of the nature of the heating, but the cooling of bottle material. The higher the mold temperature, the slower the cooling of the blown bottle. It has also been shown that the increase in topload values is due to the panel section being thicker; the loads put on the empty bottle are absorbed by the panel section of the bottle [50].

The effect of cooling the blown bottle through the blow mold on the degree of crystallinity was parabolic, and for temperatures from $5^{\circ} \mathrm{C}$ to $35^{\circ} \mathrm{C}$, raising the mold temperature caused a decrease in crystallinity $\left(\right.$ at $5^{\circ} \mathrm{C}$, the degree of crystallinity was the highest at $33 \%$ ). At the same time, when the mold temperature was increased to about $25^{\circ} \mathrm{C}$, the pressure resistance was increased, but it was also noticeable that the thickness of the bottle wall increased 
in the region where fracture started during the pressure resistance test. For mold temperatures of between $35^{\circ} \mathrm{C}$ and $40^{\circ} \mathrm{C}$, the degree of crystallinity reached a minimum value $(24 \%)$, while above $40^{\circ} \mathrm{C}$ the degree of crystallinity began to increase. The degree of crystallinity is generally slightly higher for bottles produced with a low mold surface temperature and long residence time, compared with those produced with a high mold surface temperature and low residence time. In summary, it can be seen that above a mold temperature of $25^{\circ} \mathrm{C}$, the pressure resistance and wall thickness in the area of label of the bottle decreased with increasing mold temperature. Since no correlation can be found between the degree of crystallinity (measured by Differential Scanning Calorimetry - DSC), wall thickness and pressure resistance of the bottle, the pressure resistance of the bottle cannot only be explained by the thickness distribution and degree of crystallinity in the area where the bottle begins to crack (i.e. in the area of the least pressure resistance) [50]. There must be an additional factor, and it is likely that this factor is the relaxation of the amorphous phase.

In the SBM process with hot and cold mold tests, the greatest difficulty arises from the measurement of preform heating in the furnaces, which is the most important process in terms of the impact on the properties of the cold fill bottles [51]. It has been shown that a higher temperature of the preform causes a lower pressure resistance of the bottle and lower top-load strength; this is because at a higher temperature, more material is being moved from the shoulder and label parts of bottle to the base [52].

Experiments and numerical simulations have shown that the optimal performance of the stretch-blow phase for cold filling bottles is achieved when the temperature of the preform is neither homogeneous nor monotonic [51, 53-55]. An optimal temperature distribution is obtained by controlling the amount of energy irradiated by the various layers of IR lamps forming the furnace and by tuning the delay time between exiting the furnace and the stretch forming phase. Furthermore, factors such as the ambient temperature, the thermo-optic and geometric preform properties or the production speed may change, and the ISBM machine must be able to compensate for these effects. The last of these depends on the low thermal conductivity of PET [56] and on the heating process, resulting in non-negligible thermal gradients across the entire thickness of the preform wall [33]. Experimental and numerical results lead us to conclude that the temperature distribution over the sheet thickness $(1.5 \mathrm{~mm})$ rapidly attains an equilibrium temperature during the cooling stage. However, due to the poor conductivity of the PET, a non-uniform temperature distribution still appears over the irradiated faces of the sheet after the cooling stage [57].

After the preform exits the furnace, the outer preform wall surface has a temperature about $15^{\circ} \mathrm{C}$ higher than the internal wall surface. However, when transport- ing the preform from the furnace to the blow mold, the temperature gradient decreases and disappears after approximately 12 seconds to change the sign later; after 12 seconds the temperature of the external wall side is lower than that of the internal one, with a difference of approximately $3^{\circ} \mathrm{C}$ [33]. From investigation, the following requirements can be identified: (i) lowering the external surface temperature of the preform to avoid cold crystallization, which may limit the blowing ability and alter the mechanical properties of the bottles; and (ii) reducing the temperature gradient in the preform thickness. To meet these requirements, two parameters must be controlled: the residence time in the oven, and the total power of the oven [33].

The preform heating process is affected by too many variables to allow the use of constant-power furnaces [50]. The settings of the process parameters (such as the distribution of lamp power) therefore require tuning whenever the product type changes, and sometimes also during normal operation of the ISBM machine. Today, experienced technicians find acceptable working conditions through trial and error, since the preforms are preheated by an infrared heating oven system, which is often an open loop system [55] that relies heavily on a trial and error approach to adjust the lamp power settings. However, modern blow molding machines, have close loop control system with two pyrometers before the entrance to the blow mold which measurements allows to control the lamps in furnace to stabilize the temperature of the preforms. According to information reported by Saggin et al. [38], it appears that the temperature of preforms heated in high-class heaters usually fluctuates by $2-3^{\circ} \mathrm{C}$.

Saggin et al. [38] described a system for the measurement of the internal and external temperature profiles of PET preforms after the reheating step used in the ISBM process. A measuring system based on two thermopiles for the identification of the internal temperature profile and a thermal camera for the measurement of the external profile was designed. The temperature profile of the preforms leaving the infrared oven was measured for various machine configurations. The parameters examined were the intensity of infrared lamps and the production speed, which determines the speed in the furnace. Both parameters were initially set to average values for standard production conditions, and were then modified by applying a minimal change, which according to the operator's experience should cause a detectable effect on the quality of the bottles. The lamp intensity was reduced by $5 \%$ compared to the nominal value, referred to as the "standard"; a decrease of the same amount was applied to the different layers of IR lamps in the furnace. The line speed was reduced by $10 \%$ compared to the standard state, in order to simulate a small change in production volume. After selecting the parameters, the machine was run for five minutes without loading the performs, so that the system could stabilize. Three repetitions were 
made for each configuration, and the device was turned off for about 10 minutes between repetitions.

This research showed that the thermal imaging camera is an inadequate tool for the dynamic measurement of preform temperatures (only static measurements of the preform temperature can be made with a thermal imaging camera). The problem with measuring the temperature of the preform based on the radiation emitted from the preform material lies the fact that the emissivity of the preform material depends on many factors, such as the degree of crystallinity [46], the injection production procedure, the geometry of the preform and the actual material composition. This research also shows that when the preform is moved from the preheating furnace to the blow molds, it cools at a rate of about $0.5^{\circ} \mathrm{C} / \mathrm{s}$ (although no environmental parameters were given) [38]. This has a strong effect on the properties of the bottles produced, since the preform residence time between the furnace and the mold is usually $3-8$ seconds.

\section{SUMMARY}

An analysis of the literature shows that the relaxation of the amorphous phase has the greatest impact on the thermal stability and pressure resistance of the bottle. At the same time, the thermal stability of the bottle increases, and the pressure strength decreases when the relaxation of the amorphous phase is increased, and the crystallites increase to the largest size possible without causing thermal whitening of the material. The measure of relaxation of the amorphous phase is based on the amount of oriented and "rigid" amorphous phase, since the higher the degree of relaxation of the amorphous phase, the smaller the amounts of oriented and rigid amorphous phase. As discussed above, the amounts of oriented and rigid amorphous phase determine the mechanical and thermal properties of the bottle material; however, determining the amounts of amorphous phase and rigid amorphous phase by measuring the microscopic properties of the bottle material is difficult, costly and unreliable, since these measurements is carried out locally on samples cut from a bottle. The mesomorphic structures can be directly detected using SAXS, IR and polarized light methods.

The main parameters of the hot mold SBM process that affect the properties of the hot filling bottle are the intrinsic viscosity of the preform material, the power profile of the heating lamps in the heating oven (there are seven levels of heating lamps), the heating time in the oven and the associated time of temperature-induced crystallization prior to the SBM process, the speed of the stretching rod, the pre-blow delay due to the stretching rod position, the pre-blow pressure, pre-blow duration, main blow pressure, duration of the main blow, temperature profile of the heated blow mold (there are two heat zones for the blow mold, the lateral surface of the bottles and base zone), duration of annealing in the mold, cooling air tempera- ture of a bottle in a blow mold fed by a stretching rod, and the pressure in the feed branch for air cooling of a bottle in a blow mold fed by a stretching rod. Thus, the properties of a bottle for hot fill can be influenced by as many as 20 factors during the SBM process with a hot mold.

Our analysis of the literature shows that in order to obtain the highest heat resistance of the bottle, the preforms should be heated as rapidly as possible to the highest temperatures, to minimize the formation of an oriented amorphous phase during the SBM process. In addition, the temperature of the blow mold should be as high as possible to maximize the relaxation of the oriented amorphous phase and support the temperature crystallization of the molded bottle. It follows that the most important factors affecting the properties of hot fill bottles are the intrinsic viscosity of the preform material, the power profile of the heating furnaces, the temperature profile of the blow mold, the blow-in time in the blow mold, and the pressure in the branch supplying air cooling for the bottle in the blow mold fed by rod stretching. Thus, up to 12 factors may require analysis. The intrinsic viscosity of the preform material is very difficult to stabilize, since during the injection process, the intrinsic viscosity of the preform always decreases relative to the intrinsic viscosity of the granulate. The size of this decrease is about $0.01-0.02 \mathrm{dl} / \mathrm{g}$.

It should also be noted that the greatest number of independent factors are associated with the processes of heating preforms in a heating furnace and heating the bottle in a blow mold. Hence, the description of the preform heating process in furnaces can often be reduced from eight factors to one, i.e. the total power of the heating furnace. In the same way, the process of heating the bottles in the blow mold can be minimized from four factors to two, i.e. the overall temperature increases in all heating zones of the blow mold, and the time of heating the bottle in the blow mold. In total, there are three factors affecting the annealing process in the SBM process with the hot mold.

In addition to the SBM process, the filling process itself also affects the properties of the hot fill bottle. There are three main parameters of the hot filling process that affect the properties of the bottle: the time from opening the blow molds to the start of filling, the temperature of the liquid to be filled, and the annealing time (i.e. the time between filling and the start of the cooling process). A bottle leaving the blow mold has a temperature of about $40^{\circ} \mathrm{C}$, which is well below the glass transition temperature, meaning that the time between opening the blow molds and the start of the filling process should theoretically be unimportant; however, the TES company have found that this time is important.

Although many simulations of the SBM process with a cold mold have been described in literature [58-60], there are few such simulations for the SBM process with a hot mold. Numerous models of PET material are available that can be used in the SBM process [61-63], but 
these are simplified and do not simultaneously take into account the thermally induced crystallization, the orientation of the amorphous and crystalline phase, cavitations in the volume of the material, and microcavities occurring at the crystalline boundary with the amorphous phase.

\section{REFERENCES}

[1] Wawrzyniak P., Karaszewski W.: Polimery 2020, 65, 346. https://dx.doi.org/10.14314/polimery.2020.5.2

[2] Boyd T.J.: "Transient crystallization of poly(ethylene terephthalate) bottles", The University of Toledo, Toledo 2004.

[3] Ishinabe M., Tashiro K., Yamamoto H., Imaeda K.: Seikei-Kakou 2013, 25, 393.

https://doi.org/10.4325/seikeikakou.25.393

[4] Weissmann D.: "Applied Plastics Engineering Handbook: Processing and Materials" (Ed. Kutz M.), William Andrew, 2011, pp. 603-623. https://doi.org/10.1016/B978-0-323-39040-8.00034-1

[5] Ishinabe M., Yamashita Y., Tsutsumiuchi K. et al.: Transactions of the Materials Research Society of Japan 2017, 42, 107. https://doi.org/10.14723/tmrsj.42.107

[6] Fei G., PuX., Zhuang T.et al.: Ultrasonics-Sonochemistry 2018, 40, 442. https://doi.org/10.1016/j.ultsonch.2017.07.036

[7] Jin C., Murphy J.N.: ACS Nano 2014, 8, 3979. https://doi.org/10.1021/nn5009098

[8] Viswanath V., Maity S., Bochinski J.R. et al.: Macromolecules 2013, 46, 8596. https://doi.org/10.1021/ma401855v

[9] Qian Q., Wang J., Yan F., Wang Y.: Angewandte Chemie International Edition 2014, 53, 4465. https://doi.org/10.1002/anie.201310714

[10] Baer G.M., Small W., Wilson T.S. et al.: BioMedical Engineering OnLine 2007, 6, 43. https://doi.org/10.1186/1475-925X-6-43

[11] Zhang H., Xia H., Zhao Y.: Journal of Materials Chemistry 2012, 22, 845. https:/doi.org/10.1039/C1JM14615G

[12] Zhang H., Fortin D., Xia H., Zhao Y.: Macromolecular Rapid Communications 2013, 34, 1742. https://doi.org/10.1002/marc.201300640

[13] Zhang H., Han D., Yan Q. et al.: Journal of Materials Chemistry A 2014, 2, 13373. https://doi.org/10.1039/C4TA02463J

[14] Zhang H., Xia H., Zhao Y.: ACS Macro Letters 2014, 3, 940. https://doi.org/10.1021/mz500520b

[15] Mohr R., Kratz K., Weigel T. et al.: Proceedings of the National Academy of Sciences of the USA 2006, 103, 3540 . https://doi.org/10.1073/pnas.0600079103

[16] Schmidt A.M.: Macromolecular Rapid Communications 2006, 27, 1168. https://doi.org/10.1002/marc.200600225

[17] Fei G., Li G., Wu L., Xia H.: Soft Matter 2012, 8, 5123. https://doi.org/10.1039/C2SM07357A

[18] Fei G., Tuinea-Bobe C., Li D. et al.: RSC Advances 2013, 3, 24132. https://doi.org/10.1039/C3RA43640C

[19] Koerner H., Price G., Pearce N.A. et al.: Nature Materials 2004, 3, 115. https://doi.org/10.1038/nmat1059

[20] Williges C., Chen W., Morhard C.: Langmuir 2013, 29, 989.

https://doi.org/10.1021/la303991x

[21] Li G., Fei G., Liu B. et al.: RSC Advances 2014, 4, 32701. https://doi.org/10.1039/C4RA04586F

[22] Li G., Fei G., Xia H. et al.: Journal of Materials Chemistry 2012, 22, 7692. https://doi.org/10.1039/C2JM30848G

[23] Li G., Yan Q., Xia H., Zhao Y.: ACS Applied Materials and Interfaces 2015, 7, 12067. https://doi.org/10.1021/acsami.5b02234

[24] Li G., Zhang H., Fortin D. et al.: Langmuir 2015, 31, 11709. https://doi.org/10.1021/acs.langmuir.5b03474

[25] Liu B., Xia H., Fei G. et al.: Macromolecular Chemistry and Physics 2013, 214, 2519.

https://doi.org/10.1002/macp.201300320

[26] Lu X., Fei G., Xia H., Zhao Y.: Journal of Materials Chemistry A 2014, 2, 16051. https://doi.org/10.1039/C4TA02726D

[27] Han J., Fei G., Li G., Xia H.: Macromolecular Chemistry and Physics 2013, 214, 1195. https://doi.org/10.1002/macp.201200576

[28] Li Y., Tong R., Xia H. et al.: Chemical Communications 2010, 46, 77391. https://doi.org/10.1039/C0CC02628J

[29] Rosenthal I., Sostaric J.Z., Riesz P.: Ultrasonics Sonochemistry 2004, 11, 349. https://doi.org/10.1016/j.ultsonch.2004.03.004

[30] Spinelli A.C., Sant'Ana A.S., Pacheco-Sanchez C.P., Massaguer P.R.: International Journal of Food Microbiology 2010, 137, 295. https://doi.org/10.1016/j.ijfoodmicro.2009.11.003

[31] Mahendrasingam A., Blundell D.J., Martin C. et al.: Polymer 2000, 41, 7803. https://doi.org/10.1016/S0032-3861(00)00129-4

[32] Menary G.H., Tan C.W., Harkin-Jones E.M.A. et al.: Polymer Engineering and Science 2012, 52, 671. https://doi.org/10.1002/pen.22134

[33] Billon N., Haudin J.M., Vallot C., Babin C.: International Polymer Processing 2015, 4, 487. https://doi.org/10.3139/217.3066

[34] Prasath R.G.R., Newton T., Danyluk S.: Manufacturing Letters 2018, 15, 9. https://doi.org/10.1016/j.mfglet.2017.12.010

[35] Brandau O.: "Blow molds" in: "Stretch Blow Molding" (Ed. Brandau O.), William Andrew, 2016.

[36] Haudin J.M., Boyer S.A.E.: International Polymer 
Processing Journal of the Polymer Processing Society 2017, 32 (5), 545.

https://doi.org/10.3139/217.3593

[37] Hu Y.S., Hiltner A., Baer E.: Journal of Applied Polymer Science 2005, 98, 1629.

https://doi.org/10.1002/app.22214

[38] Saggin B., Tarabini M., Scaccabarozzi D. et al.: Measurement 2019, 133, 412.

https://doi.org/10.1016/j.measurement.2018.10.044

[39] Giles G.A., Bain D.R.: "Technology of Plastics Packaging for the Consumer Market", Wiley-Blackwell, 2001.

[40] Schoukens G., Samyn P., Maddens S., van Audenaerde T.: Journal of Applied Polymer Science 2003, 87, 1462. https://doi.org/10.1002/app.11644

[41] Mody R., Lofgren E.A., Jabarin S.A.: Journal of Plastic Film \& Sheeting 2001, 17, 152. https://doi.org/10.1106/Y0FP-L790-0KEE-YV6J

[42] Wingard C.D.: Journal of Thermal Analysis 1997, 49, 385. https://doi.org/10.1007/BF01987461

[43] Haworth B., Dong Z.W., Davidson P.: Polymer International 1993, 32, 325. https://doi.org/10.1002/pi.4990320317

[44] Shih W.H.: Polymer Engineering and Science 1994, 34, 1121. https://doi.org/10.1002/pen.760341405

[45] Demirel B., Daver F.: Polymer Engineering and Science 2013, 53, 868. https://doi.org/10.1002/pen.23333

[46] Ruvolo-Filho A., De Carvalho G.M.: Journal of Macromolecular Science, Part B: Physics 1996, 35, 255. https://doi.org/10.1080/00222349608212384

[47] Allahkarami M., Ahmed R.U., Bandla S., Hanan J.: SPE ANTEC 2014, pp. 2350-2354.

[48] Brighenti R., Artoni F., Vernerey F. et al.: Journal of the Mechanics and Physics of Solids 2018, 113, 65. https://doi.org/10.1016/j.jmps.2018.01.012

[49] Silberman A., Omer M., Ophir A., Kenig S.: Conference proceedings at ANTEC '98: plastics on my mind, Society of Plastics Engineers, Atlanta, Georgia, April 26-April 30, 1998, 44 (1), 803.

[50] Demirel B.: Polymer Testing 2017, 60, 220. https://doi.org/10.1016/j.polymertesting.2017.03.030

[51] Bordival M., Schmidt F.M., Le Maoult Y., Velay V.: Polymer Engineering and Science 2009, 49, 783.

https://doi.org/10.1002/pen.21296

[52] Daver F., Demirel B.: Journal of Materials Processing Technology 2012, 212, 2400.

https://doi.org/10.1016/j.jmatprotec.2012.06.004

[53] Cosson B., Schmidt F., Le Maoult Y., Bordival M.: International Journal of Material Forming 2011, 4, 1. https://doi.org/10.1007/s12289-010-0985-8

[54] Ranjbar A.A., Mirsadeghi M.: Polymer Engineering and Science 2008, 48, 133. https://doi.org/10.1002/pen.20930

[55] Yang Z., Naeem W., Menary G. et al.: IFAC Proceedings 2014, 47, 766.

https://doi.org/10.3182/20140824-6-ZA-1003.01191

[56] Monteix S., Le Maoult Y., Schmidt F., Arcens J.P.: Quantitative InfraRed Thermography Journal 2004, 1, 133. https://doi.org/10.3166/qirt.1.133-150

[57] Monteix S., Schmidr P., Le Maouh Y. et al.: Journal of Materials Processing Technology 2001, 119, 90.

[58] Yang Z.J., Harkin-Jones E., Menary G.H., Armstrong C.G.: Journal of Materials Processing Technology 2004, 153-154, 20. https://doi.org/10.1016/j.jmatprotec.2004.04.203

[59] Raza S.H., Soyarslan C., Bargmann S., Klusemann B.: Computer Methods in Applied Mechanics and Engineering 2019, 344, 887.

https://doi.org/10.1016/j.cma.2018.10.007

[60] Gupta S., Uday V., Raghuwanshi A.S. et al.: APCBEE Procedia 2013, 5, 468. https://doi.org/10.1016/j.apcbee.2013.05.079

[61] Makradi A., Ahzi S., Gregory R.V., Edie D.D.: International Journal of Plasticity 2005, 21, 741. https://doi.org/10.1016/j.ijplas.2004.04.012

[62] Dusunceli N., Colak O.U.: International Journal of Plasticity 2008, 24, 1224. https://doi.org/10.1016/j.ijplas.2007.09.003

[63] Ponçot M., Addiego F., Dahoun A.: International Journal of Plasticity 2013, 40, 126. https://doi.org/10.1016/j.ijplas.2012.07.007

Received 12 XI 2019. 